\title{
Assessment of European and hybrid aspen clones efficiency based on height growth and removal percentage of petroleum hydrocarbons $-a$ field trial
}

\author{
Mir Md Abdus Salam ${ }^{1} \cdot$ Muhammad Mohsin $^{1}$ (D) Fahad Rasheed ${ }^{2} \cdot$ Muhammad Ramzan $^{3,4} \cdot$ Zikria Zafar $^{2} \cdot$ \\ Pertti Pulkkinen ${ }^{5}$
}

Received: 28 August 2019 / Accepted: 10 August 2020 / Published online: 15 August 2020

(C) The Author(s) 2020

\begin{abstract}
Soils polluted by organic or inorganic pollutants are an emerging global environmental issue due to their toxic effects. A phytoremediation experiment was conducted to evaluate the extraction potential of three European aspen clones (R2, R3, and R4) and seven hybrid aspen clones (14, 27, 34, 134, 172, 191, and 291) grown in soils polluted with hydrocarbons (includes polycyclic aromatic hydrocarbons (PAH) and total petroleum hydrocarbons (TPH)). Height growth, plant survival rates, and .hydrocarbon removal efficiencies were investigated over a 4-year period at a site in Somerharju, Luumaki Finland, to assess the remediation potential of the clones. Hydrocarbon content in the soil was determined by gas chromatography and mass spectrometry. The results revealed that hybrid aspen clones 14 and 34 and European aspen clone R3 achieved greater height growth $(171,171$, and $114 \mathrm{~cm}$, respectively) than the other clones in the study. Further, the greatest removals of PAH (90\% at depth $10-$ $50 \mathrm{~cm})$ and $(86 \%$ at depth $5-10 \mathrm{~cm})$ were observed in plot $\mathrm{G} 15$ planted with clone R2. Furthermore, the greatest TPH removal rate at 5-10 cm depth $\left(\mathrm{C}_{22}-\mathrm{C}_{40}, 97 \%\right.$; $\mathrm{C}_{10}-\mathrm{C}_{40}, 96 \%$; and $\left.\mathrm{C}_{10}-\mathrm{C}_{21}, 90 \%\right)$ was observed in plot 117 with clone 134 . However, other clones demonstrated an ability to grow in soils with elevated levels of TPH and PAH, which indicates their tolerance to hydrocarbons and their potential capacity for phytoremediation of hydrocarbon-polluted soils. Our study suggests that European aspen and hybrid aspen clones could be used for the remediation of soils polluted with PAH and TPH.
\end{abstract}

Keywords European aspen $\cdot$ Hybrid aspen $\cdot$ Hydrocarbons $\cdot$ Phytoremediation

Mir Md Abdus Salam and Muhammad Mohsin contributed equally to this work.

Responsible Editor: Elena Maestri

Muhammad Mohsin

muham@uef.fi

1 School of Forest Sciences, University of Eastern Finland, Yliopistokatu 7, P.O. Box 111, 80100 Joensuu, Finland

2 Department of Forestry \& Range Management, University of Agriculture, Faisalabad 38000, Pakistan

3 College of Forestry, Nanjing Forestry University, Nanjing 210037 , China

4 Department of Soil and Water Conservation and Desertification, Beijing Forestry University, Beijing 100083, China

5 Natural Resources Institute Finland (Luke), Haapastensyrjä Research Unit, Haapastensyrjäntie 34, 12600 Layliainen, Finland

\section{Introduction}

Globally, petroleum is considered an essential component of modern industrial society (Khan et al. 2013). Unfortunately, sites are contaminated with petroleum hydrocarbons due to the processing of petroleum derivatives through extraction, transportation, refining, and usage (PAH; Khan et al. 2013; Nam et al. 2008). Further, petroleum-based products are a known energy source for daily life and industrial performance, although the discharge of these products into the environment results in ecosystem damage and genetic mutation, such as pollutant deposition in plant tissues and animals (Guarino et al. 2017), as well as negatively influences plant growth and development (Nie et al. 2011). Moreover, the occurrence of petroleum pollutants in the soil strongly affects soil chemical properties, microbial populations, and performance (Guo et al. 2012; Leme et al. 2012) and also negatively impacts the capacity of plants and microbes to absorb water and nutrients from the soil (Kathi and Khan 2011). Crude oil is a complex 
combination of hydrocarbon and non-hydrocarbon compounds and has diverse effects on soil microorganisms, with the discharge of crude oil into the soil known to alter both the physical and chemical properties (Udeh et al. 2013).

The complex organic chemicals include $\mathrm{PAH}$, which are enclosed by carbon and hydrogen and have a melded ring structure, partially holding two benzene rings (Ravindra et al. 2008). In general, PAH are produced through wood and coal combustion, diesel and petrol combustion, and industrial processes and can be found in the surrounding environment, including the air, water, and soil (Semenov et al. 2017). Emissions of PAH into the soil may eventually cause fires or dangerous explosions, especially when the fumes enter restrained places (Souza et al. 2014). Furthermore, PAH are also spread naturally through forest fires and volcanic eruptions and are considered an incomplete product that is formed by the pyrolysis of fossil fuels (Wcisło 1998).

The presence of total petroleum hydrocarbons (TPH) in the soil hinders aeration, since the oil fumes produce a physical obstacle between the air and the soil, thus resulting in distortion of the soil texture. Hence, these detrimental effects lead to changes in soil redox potential, which leads to the increases in soil $\mathrm{pH}$ and the suffocation and toxicity of soil biota (Olawepo et al. 2018). Indeed, TPH are considered environmental stressors that can cover the plant root surface and prevent water and nutrient uptake. Moreover, they can enhance the production of reactive oxygen species (ROS), leading to the activation of oxidative stress in plants (Noori et al. 2018).

Globally, an average of 35 million barrels of petroleum is transported across the seas and oceans every year, and this renders the marine ecosystem susceptible to contamination (Macaulay 2015). It has been estimated by the European Environmental Agency (EEA) that there are approximately 2.5 million potentially polluted sites in Europe (EEA 33 plus the six cooperating countries). Heavy metals (HM) and petroleum products are the fundamental causes of soil contamination (Cocârță et al. 2017). Also, crude oil and petroleum elements, such as PAH, volatile aromatic hydrocarbons (VAH), benzene, toluene, ethylbenzene, and xylenes (BTEX), have affected up to approximately $53 \%$ of the polluted sites in Europe (Pinedo et al. 2013). Moreover, about $45 \%$ of groundwater in Europe is contaminated with crude oil and petroleum elements. Groundwater contamination with PAH and BTEX has increased from 6 to $15 \%$ (Panagos et al. 2013). In the European environment, PAH accounts for up to $13 \%$ of the pollutants that affect soils (due to their low water solubility and low volatility) (Istrate et al. 2018) and can be found in the soil at levels as high as $3330 \mathrm{mg} \mathrm{kg}^{-1}$ (Kołtowski et al. 2016).

In Finland, PAH, TPH, polychlorinated biphenyls, chlorophenols, and pesticides, including HM, such as arsenic $(\mathrm{As})$, lead $(\mathrm{Pb})$, copper $(\mathrm{Cu})$ and zinc $(\mathrm{Zn})$, are considered significant sources of soil pollution. These pollutants originate from the dispersion and storage of fuel-impregnated plants, diverse industrial activities, depots and garages, greenhouses, and shooting ranges (Kuusiniemi and Eklund 2008; Mohsin et al. 2019; Paccassoni et al. 2017). Moreover, the long-term persistence of inorganic pollutants in the soil causes considerable stress to forest ecosystems in the region, which then require extensive remediation (Xu 2013). However, a costeffective biological technology, such as phytoremediation (e.g., the use of specific plants and/or their rhizosphere microorganisms to decrease, destroy, and alleviate the toxic pollutants), is required to efficiently overcome the problems associated with environmental pollution with minimal ecological impact and neutralize HM- and PAH-polluted soils (Zalesny et al. 2005).

In recent years, the emerging innovative technologies for the removal of organic or inorganic pollutants have been widely explored. Formerly, prevalent remediation methods, such as physical remediation, chemical remediation, and bioremediation, have been utilized to rehabilitate polluted soils, but these methods are considered costly and likely to induce further contamination (Peng et al. 2009; Salam et al. 2019). In this context, phytoremediation has been seen as an attractive, eco-friendly, cost-efficient, and economically sustainable method to remove pollutants, using specific metal tolerant plants (Mohsin 2016; Salam et al. 2016). Phytoremediation of hydrocarbon-polluted soils is commonly driven by the process called rhizosphere degradation, in which the increased microbial activity associated with the soil, in proximity to plant roots, breaks down the hydrocarbons (Tischer and Hübner 2002).

Populus is a genus of 25-35 species of deciduous plants in the family of Salicaceae, which are native to the Northern Hemisphere. The genus has considerable genetic heterogeneity and can grow up to $50 \mathrm{~m}$ (Zacchini et al. 2011). The European aspen (Populus tremula L.) has been considered a suitable candidate for phytoremediation of soils polluted with organic and inorganic pollutants due to inherent characteristics, such as abundant genetic variation in a natural population, rapid physiological responses to environmental factors, well-characterized molecular physiology, cloning of individual tree genotype, as well as exhibiting considerable biomass production rates, a high transpiration rate, and an extensive root system (Guerra et al. 2011). The European aspen tolerates a wide range of extreme climatic and soil conditions and has been used for phytoremediation in the past due to its rapid growth and considerable biomass production rates, ability to grow in a polluted environment, as well as its capacity to remove HM and TPH from soils (Malá et al. 2007; Mukherjee 2014). Hybrid aspen (P. tremula L. $\times$ $P$. tremuloides Michx.) is a cross between the European aspen and North American trembling aspen (P. tremuloides Michx.), is one of the fastest-growing tree species in Finland, and has been widely used for phytoremediation and for biomass 
production for energy generation (Häikiö et al. 2009; Tullus et al. 2012).

Between 1947 and 1958, the Somerharju area in Southeast Finland was a creosote preservation facility for railway sleepers (Clavel 2013). Creosote oil is a by-product of tar distillation, which contains around $85 \% \mathrm{PAH}, 15 \%$ $\mathrm{TPH}$, and high concentrations of $\mathrm{C}_{10}-\mathrm{C}_{21}, \mathrm{C}_{22}-\mathrm{C}_{40}, \mathrm{C}_{10^{-}}$ $\mathrm{C}_{40}$, phenanthrene, and naphthalene (Mueller et al. 1989). In general, $20-40 \%$ of creosote is comprised of sixteen (US EPA-defined) priority PAH pollutants (Kulik et al. 2006). The soil in this area is polluted with sixteen priority PAH (previously reported by Golder Associate Corporation, Helsinki) and has become a threat to groundwater and ecosystems. As the detrimental effects of oil spillage on soils are of considerable global concern (Khan et al. 2016; Obida et al. 2018), this study would help create awareness of the potential of European aspen and hybrid aspen clones for the remediation of polluted soils in Finland, as well as in other parts of the world.

To the best of our knowledge, this field trial is the first attempt to evaluate the phytoremediation efficiency of divergent European aspen and hybrid aspen clones to remediate hydrocarbon-polluted soils at a former railway sleeper site. Principally, this study aimed to assess the growth and phytoremediation efficacy of European aspen and hybrid aspen clones in soils polluted with PAH and TPH, as well as identify potential European aspen and hybrid aspen clones that could be used to reduce PAH and TPH concentrations in polluted soils.

\section{Materials and methods}

\section{Study site and planting materials}

The experimental site "Somerharju" is located in southeastern Finland ( $60^{\circ} 55^{\prime} 00^{\prime \prime} \mathrm{N}$ and $27^{\circ} 26^{\prime} 00^{\prime \prime} \mathrm{E}$, Luumaki). During the growing season, the average monthly air temperature varies in the study area, typically from $25^{\circ} \mathrm{C}$ in the summer to $-22{ }^{\circ} \mathrm{C}$ in the winter. Daylight varies from $5 \mathrm{~h}$ in winter to $20 \mathrm{~h}$ in summer. Based on breeding experiments (cloned by micropropagation in the Haapastensyrja Unit of Natural Resources Institute Finland (Luke)), three European aspen (P. tremula) clones, R2, R3, and R4, and seven hybrid aspen (P. tremuloides Michx. $\times$ P. tremula L.) clones, 14, 27, 34, $134,172,191$, and 291, were selected for the study.

\section{Experimental design}

The total study area was $\sim 6.7$ ha, with 2 ha highly polluted with hydrocarbons. We prepared a total of 40 square plots $(20 \times 20 \mathrm{~m})$ for the planting of European aspen and hybrid aspen clones. Before the preparation of the plots, we clear cut all the other plants in the polluted area $(\sim 2 \mathrm{ha})$. Based on the pollutant concentrations, the 40 square plots were assigned to one of four blocks (I-IV). Each plot was further divided into 400 smaller sub-plots $\left(\right.$ area $1 \mathrm{~m}^{2}$ ). Next, 2-year-old European aspen or hybrid aspen trees were planted in each sub-plot at a planting density of 10,000 trees/ha (Fig. 1). All clones were planted in repetition one, except for clone 34 , because that plot had an extraordinarily high density of European aspen. Tap water was used to irrigate the plants, and some plots (e.g., H13, H14, and H15) (Fig. 1) planted with clones $134, \mathrm{R} 3$, and 291, respectively, were fertilized with NPK, to examine the effect of fertilizer application on plant growth.

\section{Growth measurements}

Height growth $(\mathrm{cm})$ of the European aspen and hybrid aspen clones, which grew for a 4-year period (2013-2017), was measured as the distance from the ground to the tallest living bud point.

\section{Soil sampling and soil characteristics}

Soil samples were collected in 2011 from the study area and were observed to be polluted with PAH, comprising sixteen priority pollutants (e.g., naphthalene, acenaphthene, acenaphthylene fluorene, phenanthrene, anthracene, fluoranthene, pyrene, benzo(a)anthracene, chrysene, benzo(b)fluoranthene, benzo(k)fluoranthene, benzo(a)pyrene, indeno(1,2,3cd)pyrene, benzo(ghi)perylene, dibenzo(a, h)anthracene, and $\mathrm{TPH}\left(\mathrm{C}_{10}-\mathrm{C}_{21}, \mathrm{C}_{10}-\mathrm{C}_{40}\right.$, and $\left.\mathrm{C}_{22}-\mathrm{C}_{40}\right)$. The area was sampled using a $20 \times 20 \mathrm{~m}$ grid, and sampling pits were excavated in each plot to a depth of 5-10 $\mathrm{cm}$ or $10-50 \mathrm{~cm}$ depths with a shovel. Five samples were taken from each plot, which included one sample from the center of the pit and the remaining four samples from the corners of the square plot. Approximately $0.25 \mathrm{~L}$ of soil was collected from each pit, mixed, and combined as a 1-L composite sample in an airtight sampling bag. The composite sample was sealed in the bag, and soil samples were then stored in cold storage for 1-2 days, until the samples were sent to the laboratory for chemical analysis.

The basic properties of the soil from different polluted plots (Mean \pm SE) were previously determined by Mukherjee et al. (2014): pH, 5-8; available N, $0.025 \pm$ $0.012 \mathrm{mg} / \mathrm{kg}$; available $\mathrm{P}, 207 \pm 36 \mathrm{mg} / \mathrm{kg}$; available $\mathrm{K}$, $510 \pm 67 \mathrm{mg} / \mathrm{kg}$; available Ca, $1272 \pm 409 \mathrm{mg} / \mathrm{kg}$; available $\mathrm{Mg}, 613 \pm 107 \mathrm{mg} / \mathrm{kg}$; available $\mathrm{Cu}, 7 \pm 5 \mathrm{mg} / \mathrm{kg}$; available $\mathrm{Pb}, 5 \pm 2.78 \mathrm{mg} / \mathrm{kg}$; available $\mathrm{Ni}, 2.10 \pm 1 \mathrm{mg} / \mathrm{kg}$; coarse sand, $11 \%$; medium sand, $42 \%$; very fine sand, $40 \%$; clay, $1 \%$; silt, $6 \%$; and sand, $21.4 \%$. 


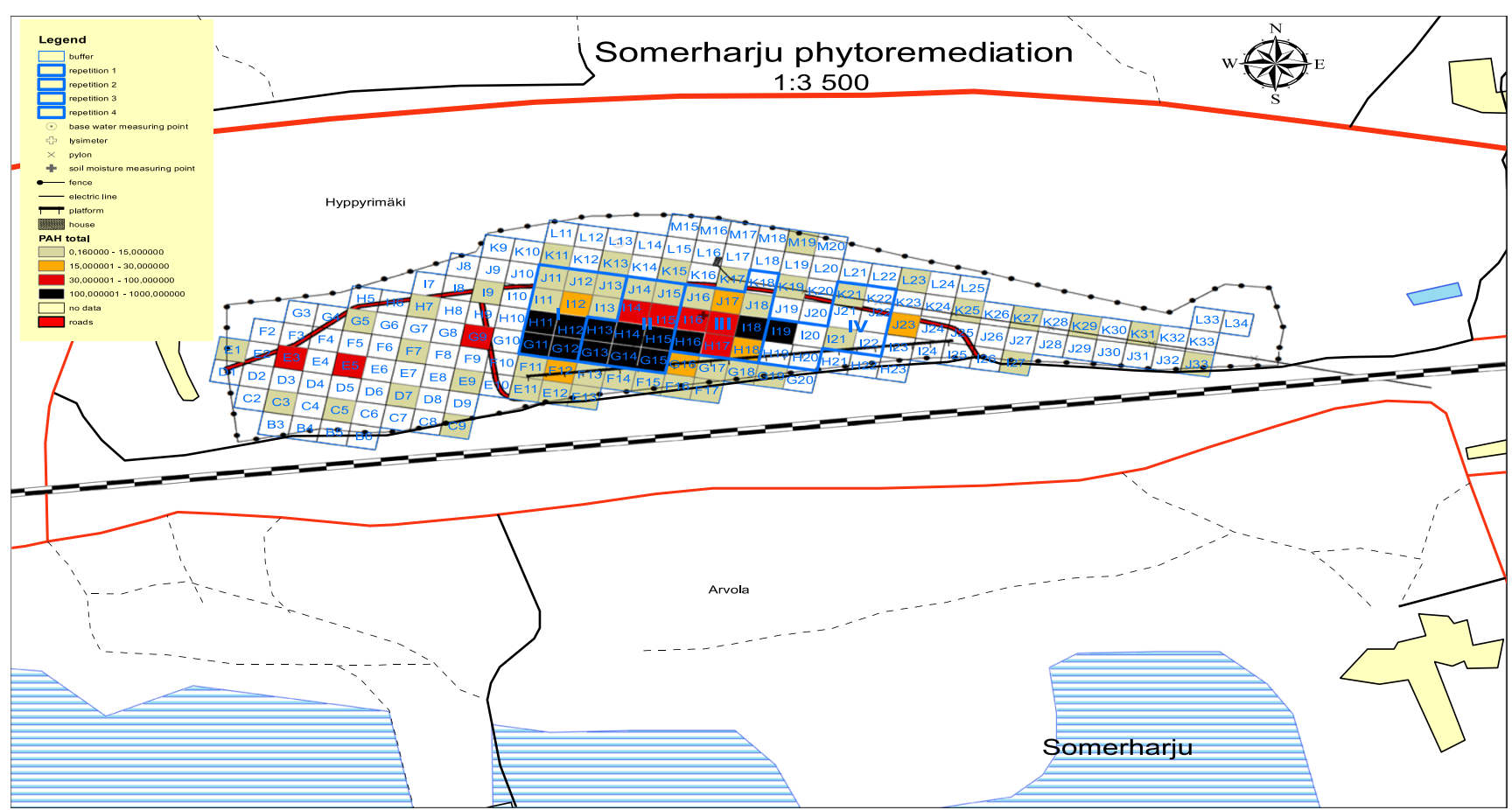

Fig. 1 Map of the Somerharju experimental site

\section{Determination of hydrocarbons (PAH and TPH) in the soils}

Soil chemical analyses were performed by ALS Finland Oy and SGS Oy (Helsinki, Finland). Soil pH, total carbon (C), and organic $\mathrm{C}$, as well as total nitrogen $(\mathrm{N})$, were measured according to the ISO 10390, ISO 10694, and ISO 13878 standards, respectively. Polycyclic aromatic hydrocarbons and TPH were analyzed using n-hexane/acetone (1:1) extraction according to the methods EPA 8270, EPA 8131, EPA 8091, ISO EN 9377-2, ISO 16703, ISO 18287, and ISO 6468, as described in Mukherjee et al. (2014). We used chromatography and mass spectrometry (GC-MS) to determine hydrocarbon concentrations in the soil. Briefly, hydrocarbons in the extracts were quantified by GC-MS in a selected ion monitoring mode. The GC-MS system consists of an Agilent $6890 \mathrm{~N}$ gas chromatograph, coupled to a mass spectrometer detector $(5975 \mathrm{C})$.

\section{Hydrocarbon removal percentage}

Pollutant removal percentage was calculated using the following expression described by Sivaram et al. (2018):

Pollutants removal $(\%)=\frac{100 \times(\mathrm{CI}-\mathrm{CT})}{\mathrm{CI}}$ where:

CI is the initial concentration of the pollutants in the soil before phytoremediation.

CT is the final concentration of the pollutants in the soil after phytoremediation.

\section{Statistical analysis}

The SPSS (version 25.0, IBM Corporation, Armonk, NY, USA) and Microsoft Excel 2016 (Redmond, WA, USA) were used for statistical analysis. The analysis of variance (ANOVA) with multiple comparisons of means was analyzed by the Tukey LSD test to determine the statistical difference in height among the clones at $p<0.05$. The multivariate analysis of variance (MANOVA) was run to examine the effect of blocks and clones on pollutant removal. The pairwise $t$ test was run to examine the differences in pollutant removal between 2011 and 2017.

\section{Results}

\section{Survival rate and mean height growth of European aspen and hybrid aspen clones}

The mean height and survival rates for European aspen and hybrid aspen clones in the polluted plots are shown in Fig. 2A and B. During the growth period, the average survival rate was 
Fig. 2 Growth of European aspen and hybrid aspen, (A) survival percentage, and (B) absolute mean height of clones grown in polluted soils. The data indicate mean values $\pm \mathrm{SE}$ (standard error) $(n=4)$. Similar lowercase letters above the bars indicate no significant differences between clones $(p>0.05)$. Error bars show the $95 \%$ confidence interval
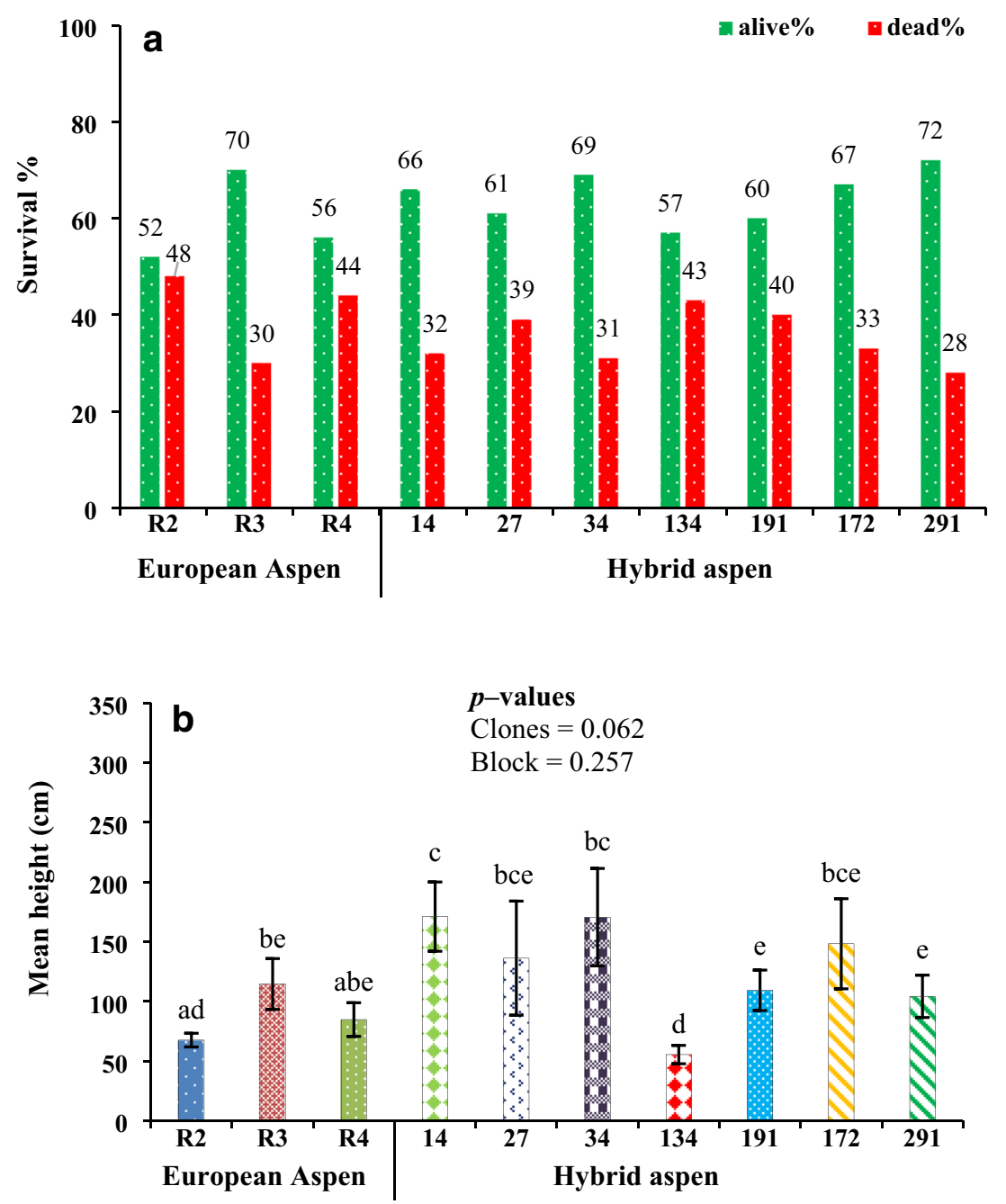

$59 \%$ for European aspen and $64 \%$ for hybrid aspen, which indicates that all the clones could survive in polluted soils (Fig. 2A). No visual symptoms of pollutant toxicity (wilting or discoloration) were observed for European aspen and hybrid aspen clones. The highest (72\%) and lowest (52\%) survival rates were observed in clones 291 and R2, respectively. Hybrid aspen clones 14 and 34 exhibited the highest height growth $(171 \mathrm{~cm})$ among all the studied clones. In the European aspen clones, R3 produced the greatest height growth $(114 \mathrm{~cm})$, followed by clones R4 and R2, respectively. The lowest height growth rate was observed in clone 134 as compared with the other hybrid aspen clones (Fig. 2B). Moreover, when exposed to fertilization, height and survival rate in clone R3 increased in comparison with clones R2 and R4. When the hybrid aspen clones 134 and 291 were subjected to fertilization, the latter displayed better height growth and survival rate than the former. Differences in mean height between the studied clones were not consistent. However, there was a slight non-significant difference among the clones for height growth, and a non-significant difference was observed between blocks I and IV (Fig. 2B).

\section{TPH and PAH removal by European aspen and hybrid aspen clones}

To estimate PAH (mean of sixteen priority pollutants) and TPH removal percentage, soil samples were collected at two depths (5-10 cm and 10-50 cm) for every clone (Tables 1 and 2). Therefore, we present a comparison among the clones and between depths in terms of pollutant removal. Initial TPH and $\mathrm{PAH}$ levels in the polluted plots were higher than the final levels after phytoremediation, but some of the plots did not show a reduction in the concentration of certain pollutants. In this study, PAH and TPH $\left(\mathrm{C}_{22}-\mathrm{C}_{40}, \mathrm{C}_{10}-\mathrm{C}_{40}\right.$, and $\left.\mathrm{C}_{10}-\mathrm{C}_{21}\right)$ concentrations at $5-10 \mathrm{~cm}$ depth were reduced by clone $\mathrm{R} 2$ in plot G15 by approximately 86 and $82 \%$, respectively. At 10 $50 \mathrm{~cm}$ depth, the removal percentage was $90 \%$ for $\mathrm{PAH}, 84 \%$ for $\mathrm{C}_{22}-\mathrm{C}_{40}, 81 \%$ for $\mathrm{C}_{10}-\mathrm{C}_{40}$, and $71 \%$ for $\mathrm{C}_{10}-\mathrm{C}_{21}$. The highest removal rate was observed in plot $\mathrm{I} 17$, planted with clone 134: $97 \%$ for $\mathrm{C}_{22}-\mathrm{C}_{40}, 96 \%$ for $\mathrm{C}_{10}-\mathrm{C}_{40}, 90 \%$ for $\mathrm{C}_{10}-$ $\mathrm{C}_{21}$, and $52 \%$ for PAH at a depth of 5-10 cm (Table 1). At a depth of $10-50 \mathrm{~cm}$, no $\mathrm{C}_{10}-\mathrm{C}_{21}, \mathrm{C}_{10}-\mathrm{C}_{40}$, and PAH were removed, and there is only $20 \%$ of $\mathrm{C}_{22}-\mathrm{C}_{40}$ (Table 2). In 
Table 1 Pollutants' concentration $(\mathrm{mg} / \mathrm{kg}$ ) and their removal percentage at 5-10 $\mathrm{cm}$ depth by European aspen and hybrid aspen clones in 2011 and 2017

\begin{tabular}{|c|c|c|c|c|c|c|}
\hline Plot & $\mathrm{pH}$ & Year & $\begin{array}{l}\mathrm{C}_{10^{-}} \\
\mathrm{C}_{21}\end{array}$ & $\begin{array}{l}\mathrm{C}_{22-} \\
\mathrm{C}_{40}\end{array}$ & $\begin{array}{l}\mathrm{C}_{10^{-}} \\
\mathrm{C}_{40}\end{array}$ & PAH \\
\hline \multirow[t]{3}{*}{ G11 } & 7 & 2011 & 152 & 455 & 606 & 161 \\
\hline & & 2017 & 180 & 280 & 474 & 190 \\
\hline & & Removal \% & -18 & 38 & 22 & -18 \\
\hline \multirow[t]{3}{*}{ G12 } & 7.7 & 2011 & 494 & 843 & 1340 & 218 \\
\hline & & 2017 & 240 & 510 & 750 & 290 \\
\hline & & Removal \% & 51 & 44 & 43 & -33 \\
\hline \multirow[t]{3}{*}{ G13 } & 6.6 & 2011 & 265 & 524 & 789 & 488 \\
\hline & & 2017 & 140 & 280 & 420 & 150 \\
\hline & & Removal \% & 47 & 47 & 47 & 69 \\
\hline \multirow[t]{3}{*}{ G14 } & 6.9 & 2011 & 176 & 1022 & 735 & 215 \\
\hline & & 2017 & 290 & 630 & 920 & 265 \\
\hline & & Removal \% & -65 & 38 & -25 & -23 \\
\hline \multirow[t]{3}{*}{ G15 } & 5.7 & 2011 & 570 & 1780 & 2350 & 471 \\
\hline & & 2017 & 100 & 320 & 420 & 65 \\
\hline & & Removal \% & 82 & 82 & 82 & 86 \\
\hline \multirow[t]{3}{*}{ H11 } & 6.6 & 2011 & 174 & 747 & 40 & 481 \\
\hline & & 2017 & 54 & 120 & 170 & 42 \\
\hline & & Removal \% & 68 & 83 & -325 & 91 \\
\hline \multirow[t]{3}{*}{ H12 } & 6 & 2011 & 173 & 1080 & 1250 & 179 \\
\hline & & 2017 & 170 & 370 & 540 & 140 \\
\hline & & Removal \% & 2 & 66 & 57 & 22 \\
\hline \multirow[t]{3}{*}{ H13 } & 5.7 & 2011 & 332 & 1530 & 1860 & 422 \\
\hline & & 2017 & 160 & 400 & 560 & 170 \\
\hline & & Removal \% & 52 & 73 & 70 & 62 \\
\hline \multirow[t]{3}{*}{ H14 } & 6.1 & 2011 & 556 & 2120 & 2675 & 532 \\
\hline & & 2017 & 1090 & 1450 & 2550 & 1050 \\
\hline & & Removal \% & -96 & 32 & 5 & -97 \\
\hline \multirow[t]{3}{*}{ H15 } & 5.5 & 2011 & 370 & 1700 & 2070 & 714 \\
\hline & & 2017 & 340 & 800 & 1100 & 310 \\
\hline & & Removal \% & 8 & 53 & 47 & 57 \\
\hline \multirow[t]{3}{*}{ H16 } & 5.4 & 2011 & 290 & 930 & 1220 & 180 \\
\hline & & 2017 & 62 & 140 & 210 & 160 \\
\hline & & Removal \% & 79 & 85 & 83 & 11 \\
\hline \multirow[t]{3}{*}{ H17 } & 5.5 & 2011 & 64 & 330 & 394 & 34 \\
\hline & & 2017 & 25.5 & 82 & 104.5 & 19.35 \\
\hline & & Removal \% & 60 & 75 & 73 & 43 \\
\hline \multirow[t]{3}{*}{ H18 } & 5.7 & 2011 & 30 & 180 & 210 & 16 \\
\hline & & 2017 & 20 & 50 & 61 & 25 \\
\hline & & Removal \% & 33 & 72 & 71 & -56 \\
\hline \multirow[t]{3}{*}{ I11 } & 6.5 & 2011 & 12 & 106 & 118 & 6.7 \\
\hline & & 2017 & 20 & 20 & 40 & 7.7 \\
\hline & & Removal \% & -67 & 81 & 66 & -15 \\
\hline \multirow[t]{3}{*}{ I12 } & 6.5 & 2011 & 17 & 73 & 90 & 15.5 \\
\hline & & 2017 & 20 & 25 & 40 & 5,4 \\
\hline & & Removal \% & -18 & 66 & 56 & 65 \\
\hline \multirow[t]{2}{*}{ I13 } & 6.6 & 2011 & 16 & 159 & 174 & 9.87 \\
\hline & & 2017 & 44 & 100 & 140 & 42 \\
\hline
\end{tabular}


Table 1 (continued)

\begin{tabular}{|c|c|c|c|c|c|c|}
\hline Plot & $\mathrm{pH}$ & Year & $\begin{array}{l}\mathrm{C}_{10^{-}} \\
\mathrm{C}_{21}\end{array}$ & $\begin{array}{l}\mathrm{C}_{22-} \\
\mathrm{C}_{40}\end{array}$ & $\begin{array}{l}\mathrm{C}_{10^{-}} \\
\mathrm{C}_{40}\end{array}$ & PAH \\
\hline & & Removal \% & -175 & 37 & 20 & -326 \\
\hline \multirow[t]{3}{*}{ I14 } & 6.4 & 2011 & 41 & 191 & 232 & 39.9 \\
\hline & & 2017 & 58 & 130 & 190 & 36 \\
\hline & & Removal \% & -41 & 32 & 18 & 7 \\
\hline \multirow[t]{3}{*}{ I15 } & 6.3 & 2011 & 48 & 278 & 326 & 89.6 \\
\hline & & 2017 & 260 & 270 & 530 & 210 \\
\hline & & Removal \% & -442 & 3 & -63 & -134 \\
\hline \multirow[t]{3}{*}{ I16 } & 5.6 & 2011 & 81 & 260 & 341 & 43 \\
\hline & & 2017 & 81 & 140 & 220 & 220 \\
\hline & & Removal \% & 0 & 46 & 35 & -412 \\
\hline \multirow[t]{3}{*}{ I17 } & 5.5 & 2011 & 200 & 740 & 940 & 96 \\
\hline & & 2017 & 20 & 24 & 40 & 46 \\
\hline & & Removal \% & 90 & 97 & 96 & 52 \\
\hline \multirow[t]{3}{*}{ I18 } & 5.4 & 2011 & 350 & 1200 & 1550 & 160 \\
\hline & & 2017 & 78 & 150 & 220 & 290 \\
\hline & & Removal \% & 78 & 88 & 86 & -81 \\
\hline \multirow[t]{3}{*}{ J16 } & 5.8 & 2011 & 20 & 25 & 40 & 3 \\
\hline & & 2017 & 21 & 20 & 40 & 5.05 \\
\hline & & Removal \% & -5 & 20 & 0 & -68 \\
\hline \multirow[t]{3}{*}{ J17 } & 5.8 & 2011 & 37 & 180 & 217 & 18 \\
\hline & & 2017 & 20 & 41 & 55 & 11 \\
\hline & & Removal \% & 46 & 77 & 75 & 39 \\
\hline \multirow[t]{3}{*}{ J18 } & 5.8 & 2011 & 20 & 85 & 105 & 8,60 \\
\hline & & 2017 & 20 & 20 & 40 & 3.70 \\
\hline & & Removal\% & 0 & 76 & 62 & 56 \\
\hline
\end{tabular}

addition, no removals occurred in the fertilized plots H14 and $\mathrm{H} 15$, planted with clones R3 and 291, respectively. In contrast, $74 \% \mathrm{C}_{22}-\mathrm{C}_{40}, 70 \% \mathrm{C}_{10}-\mathrm{C}_{40}, 62 \% \mathrm{PAH}$, and $52 \% \mathrm{C}_{10}-$ $\mathrm{C}_{21}$ were removed in plot $\mathrm{H} 13$, planted with clone 134 (with fertilizer) at 5-10 cm depth. At 10-50 cm depth, no reduction was observed for $\mathrm{C}_{10}-\mathrm{C}_{21}$ (increased by $207 \%$ ) and $\mathrm{C}_{10}-\mathrm{C}_{40}$ (increased by 5\%), although a 20 and $4 \%$ decrease were observed for $\mathrm{C}_{22}-\mathrm{C}_{40}$ and $\mathrm{PAH}$, respectively.

\section{Total mean removal rate of PAH and TPH from blocks I to III}

The total mean removal rate of $\mathrm{PAH}, \mathrm{C}_{10}-\mathrm{C}_{21}, \mathrm{C}_{22}-\mathrm{C}_{40}$, and $\mathrm{C}_{10}-\mathrm{C}_{40}$ from blocks I-III at a depth of $5-10 \mathrm{~cm}$ was 18,22 , 61 , and $50 \%$, respectively (Fig. 3A). A similar trend at 10-50 cm depth was observed, for example, $\mathrm{C}_{10}-\mathrm{C}_{21}(32 \%), \mathrm{C}_{22}-$ $\mathrm{C}_{40}(44 \%)$, and $\mathrm{C}_{10}-\mathrm{C}_{40}(37 \%)$, while $\mathrm{PAH}$ concentration increased by approximately 13\% (Fig. 3B). A significant difference was observed among the clones in the soil samples collected at a depth of 5-10 cm, but no significant differences between the blocks were found (Fig. 3A). Non-significant differences among the clones and blocks were seen when the pollutant level was measured in the soil samples collected at a depth of 10-50 cm (Fig. 3B). Greater pollutant removal was observed for TPH compared to PAH. Moreover, the greatest pollutant removals were found at a depth of $5-10 \mathrm{~cm}$ compared with $10-50 \mathrm{~cm}$. A significant reduction in $\mathrm{PAH}$ was only observed in the 5-10 cm soil zone. However, the degradation of PAH and TPH was most pronounced in the upper soil surface $(5-10 \mathrm{~cm})$ and decreased with increasing depth.

\section{Discussion}

The present study investigates the phytoremediation potential of three European aspen and seven hybrid aspen clones in polluted petroleum soils. During the experiment, the aspen plants grown in polluted soils did not exhibit stress symptoms (by visual observations). However, some of the clones died, which may have resulted from specific environmental factors, such as planting methods, excessive or insufficient rainfall, disease/ pests, weed competition, and contamination (Nichols et al. 
Table 2 Pollutants' concentration $(\mathrm{mg} / \mathrm{kg}$ ) and their removal percentage at $10-50 \mathrm{~cm}$ depth by European aspen and hybrid aspen clones in 2011 and 2017

\begin{tabular}{|c|c|c|c|c|c|}
\hline Plot & Year & $\begin{array}{l}\mathrm{C}_{10^{-}} \\
\mathrm{C}_{21}\end{array}$ & $\begin{array}{l}\mathrm{C}_{22-} \\
\mathrm{C}_{40}\end{array}$ & $\begin{array}{l}\mathrm{C}_{10^{-}} \\
\mathrm{C}_{40}\end{array}$ & PAH \\
\hline \multirow[t]{3}{*}{ G11 } & 2011 & 75 & 324 & 399 & 30 \\
\hline & 2017 & 48 & 110 & 160 & 42 \\
\hline & Removal \% & 36 & 66 & 60 & -40 \\
\hline \multirow[t]{3}{*}{ G12 } & 2011 & 1620 & 954 & 2580 & 202 \\
\hline & 2017 & 160 & 420 & 580 & 150 \\
\hline & Removal \% & 90 & 56 & 78 & 26 \\
\hline \multirow[t]{3}{*}{ G13 } & 2011 & 455 & 567 & 1020 & 428 \\
\hline & 2017 & 280 & 220 & 500 & 350 \\
\hline & Removal \% & 38 & 61 & 51 & 18 \\
\hline \multirow[t]{3}{*}{ G14 } & 2011 & 179.5 & 605 & 433 & 179 \\
\hline & 2017 & 290 & 635 & 915 & 205 \\
\hline & Removal \% & -62 & -5 & -111 & -15 \\
\hline \multirow[t]{3}{*}{ G15 } & 2011 & 293.5 & 887 & 1180 & 124 \\
\hline & 2017 & 84 & 140 & 225 & 12.5 \\
\hline & Removal \% & 71 & 84 & 81 & 90 \\
\hline \multirow[t]{3}{*}{ H11 } & 2011 & 42 & 200 & 40 & 16,7 \\
\hline & 2017 & 23 & 35 & 58 & 19 \\
\hline & Removal \% & 45 & 83 & -45 & -14 \\
\hline \multirow[t]{3}{*}{$\mathrm{H} 12$} & 2011 & 88 & 348 & 436 & 122 \\
\hline & 2017 & 270 & 450 & 720 & 270 \\
\hline & Removal \% & -207 & -29 & -65 & -121 \\
\hline \multirow[t]{3}{*}{ H13 } & 2011 & 212 & 835 & 1050 & 436 \\
\hline & 2017 & 400 & 670 & 1100 & 420 \\
\hline & Removal \% & -89 & 20 & -5 & 4 \\
\hline \multirow[t]{3}{*}{ H14 } & 2011 & 189.5 & 688 & 875.5 & 164 \\
\hline & 2017 & 440 & 617.5 & 1075 & 435 \\
\hline & Removal \% & -93 & 10 & -23 & -165 \\
\hline \multirow[t]{3}{*}{ H15 } & 2011 & 292 & 1020 & 1310 & 312 \\
\hline & 2017 & 450 & 1100 & 1600 & 440 \\
\hline & Removal \% & -54 & -8 & -22 & -41 \\
\hline \multirow[t]{3}{*}{ H16 } & 2011 & 230 & 960 & 1190 & 84 \\
\hline & 2017 & 49 & 71 & 120 & 130 \\
\hline & Removal \% & 79 & 93 & 90 & -55 \\
\hline \multirow[t]{3}{*}{$\mathrm{H} 17$} & 2011 & 91 & 280 & 371 & 53 \\
\hline & 2017 & 20 & 44 & 59 & 6.7 \\
\hline & Removal \% & 78 & 84 & 84 & 87 \\
\hline \multirow[t]{3}{*}{$\mathrm{H} 18$} & 2011 & 47 & 270 & 317 & 23 \\
\hline & 2017 & 20 & 40 & 48 & 3 \\
\hline & Removal \% & 57 & 85 & 85 & 87 \\
\hline \multirow[t]{3}{*}{ I11 } & 2011 & 10 & 28 & 40 & 0.2 \\
\hline & 2017 & 20 & 20 & 40 & 3 \\
\hline & Removal \% & -100 & 29 & 0 & -1400 \\
\hline \multirow[t]{3}{*}{ I12 } & 2011 & 100 & 57 & 156 & 0.97 \\
\hline & 2017 & 61 & 20 & 81 & 3 \\
\hline & Removal \% & 39 & 65 & 48 & -208 \\
\hline \multirow[t]{2}{*}{ I13 } & 2011 & 10 & 21 & 24 & 1.91 \\
\hline & 2017 & 20 & 20 & 40 & 3.6 \\
\hline
\end{tabular}


Table 2 (continued)

\begin{tabular}{|c|c|c|c|c|c|}
\hline Plot & Year & $\begin{array}{l}\mathrm{C}_{10^{-}} \\
\mathrm{C}_{21}\end{array}$ & $\begin{array}{l}\mathrm{C}_{22-} \\
\mathrm{C}_{40}\end{array}$ & $\begin{array}{l}\mathrm{C}_{10^{-}} \\
\mathrm{C}_{40}\end{array}$ & PAH \\
\hline & Removal \% & -100 & 5 & -67 & -88 \\
\hline \multirow[t]{3}{*}{ I14 } & 2011 & 10 & 27 & 40 & 3.54 \\
\hline & 2017 & 20 & 26 & 45 & 8.8 \\
\hline & Removal\% & -100 & 4 & -13 & -149 \\
\hline \multirow[t]{3}{*}{ I15 } & 2011 & 10 & 74 & 84 & 24.8 \\
\hline & 2017 & 20 & 26.5 & 41 & 10.7 \\
\hline & Removal \% & -100 & 64 & 51 & 57 \\
\hline \multirow[t]{3}{*}{ I16 } & 2011 & 20 & 20 & 40 & 3 \\
\hline & 2017 & 20 & 20 & 40 & 3 \\
\hline & Removal \% & 0 & 0 & 0 & 0 \\
\hline \multirow[t]{3}{*}{ I17 } & 2011 & 20 & 25 & 40 & 3.8 \\
\hline & 2017 & 20 & 20 & 40 & 5 \\
\hline & Removal \% & 0 & 20 & 0 & -93 \\
\hline \multirow[t]{3}{*}{ I18 } & 2011 & 110 & 450 & 560 & 44 \\
\hline & 2017 & 36 & 81 & 120 & 33 \\
\hline & Removal \% & 67 & 82 & 79 & 25 \\
\hline \multirow[t]{3}{*}{ J16 } & 2011 & 20 & 36 & 40 & 3 \\
\hline & 2017 & 25 & 20 & 40 & 3 \\
\hline & Removal \% & -25 & 44 & 0 & 0 \\
\hline \multirow[t]{3}{*}{$\mathrm{J} 17$} & 2011 & 20 & 20 & 40 & 3 \\
\hline & 2017 & 20 & 20 & 40 & 0.13 \\
\hline & Removal \% & 0 & 0 & 0 & 90 \\
\hline \multirow[t]{3}{*}{ J18 } & 2011 & 20 & 20 & 40 & 3 \\
\hline & 2017 & 20 & 23 & 40 & 3 \\
\hline & Removal \% & 0 & -15 & 0 & 0 \\
\hline
\end{tabular}

2014). However, plant growth may have been affected and these plants may not have been able to tolerate the concentration of hydrocarbons in the soil (Peng et al. 2009). According to Anyasi and Atagana (2018), when plants are grown in hydrocarbon-polluted soils, they generally experience some metabolic fluctuations, for example, hormonal production and enzyme sequestration, which brings about substrate modification and boosts the activities of the enzymes.

Nguemté et al. (2018) and Shirdam et al. (2008) reported that the inhibition of plant growth can also be caused by a toxic compound in TPH, especially the low-molecularweight PAH. In some cases, site quality differences are most likely driven by nutrient concentration, physical characteristics, and water holding capacity of the soil, while differences might also be caused by climatic variables, e.g., growing degree days (Guidi Nissim et al. 2018). Moreover, petroleum hydrocarbons in contact with the soil form an impermeable coating at the surface, which prevents water circulation in the soil and gas exchange between the soil and air, resulting in the suffocation of the plant roots. As the soil becomes anaerobic, metabolic activity and the number of aerobic bacteria then decrease (Streche et al. 2018).
The highest pollutant removal rates were observed in hybrid aspen clones 134 and R2. Overall, all the clones showed adequate removal rates, but a variation was seen across different plots at the two depth levels. This could be caused by many factors; for example, the plots exhibited different pollutants and $\mathrm{pH}$ levels, the action of root exudates (which aid in improving the bioavailability of PAH to the plants), the plantspecific rhizospheric effect, and differences in the inherent nature of the plants. Tischer and Hübner (2002) found that the highest reduction (64\%) of hydrocarbon concentrations occurred in the subsoil layer rather than in the deep soil layers, as did Vervaeke et al. (2003), which is in agreement with our results. Nevertheless, PAH were found in extremely low concentrations in our soil samples, which suggests their degradation, evaporation, or transportation from the topsoil (Mukherjee et al. 2014).

According to Akinola and Njoku (2007), differences in the genetic makeup of plants produce a divergent response to contamination. Hence, the differences noted in our study can be attributed to the genetic variances among the European aspen and hybrid aspen clones. Similar findings were reported by Sivaram et al. (2018), who compared C3 and C4 plants for 
Fig. 3 Total mean removal of $\mathrm{PAH}$ and TPH concentrations from three blocks: (A) depth 5-10 $\mathrm{cm}$; (B) depth 10-50 cm. The data indicate the means $\pm \mathrm{SE}$ (standard error) $(n=4)$. Similar lowercase letters above the bars indicate no significant differences $(p>0.05)$ between years. Error bars show the $95 \%$ confidence interval
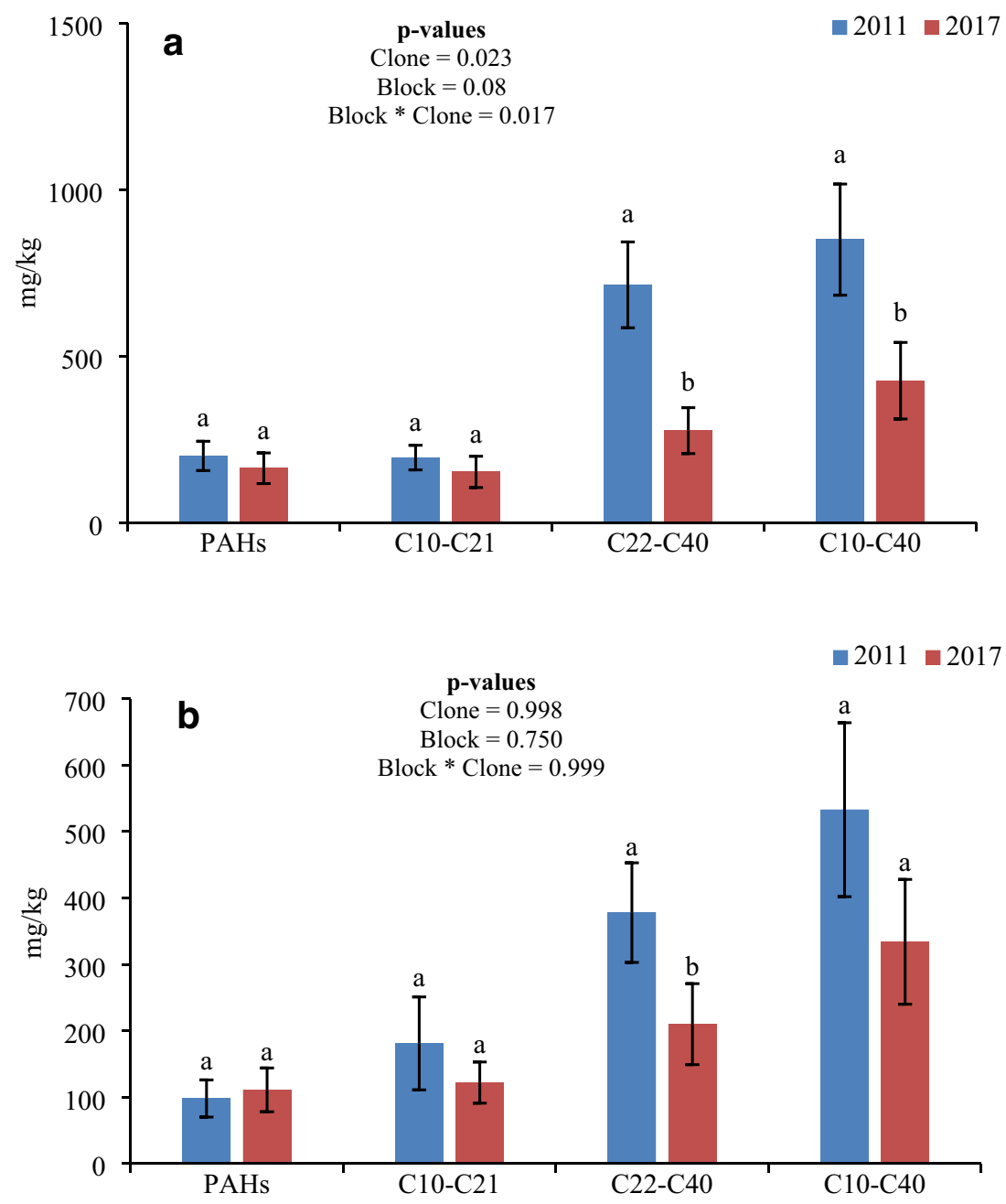

the remediation of PAH-polluted soils and stated that the remediation of PAH-polluted soils not only depends on the physicochemical property of PAH but also depends on the nature of the plants and the biologically available concentration of PAH (Reid et al. 2000; Sivaram et al. 2018). Our results regarding $\mathrm{PAH}$ degradation are in agreement with the assumption of Noori et al. (2018), who documented that the plant roots can facilitate the degradation of pollutants in the soil. They also suggested that PAH degradation could also be the result of plant enzymatic and biochemical activities, as well as the enhancement of microbial community activity in the rhizosphere. In addition, PAH degradation in polluted soils possibly occurs because of the ability of the indigenous microbial community to acclimatize to the polluted area, which results in the degradation of the targeted pollutants (García-Delgado et al. 2019; Lukic et al. 2016).

Soil $\mathrm{pH}$ plays a vital role during the biodegradation process, as well as in the growth and activity of soil microorganisms, as it regulates the solubility, mobility, and the availability of the ionized forms of pollutants (Kalita and Devi 2012). According to Kalita and Devi (2012), significant degradation of petroleum hydrocarbons commonly occurs between $\mathrm{pH} 4.5$ and 7.5, and the $\mathrm{pH}$ of the soil in our study falls within this range. As such, the $\mathrm{pH}$ levels in our soils were favorable for the degradation of TPH and PAH and also for their efficient removal from the soil. Our results have demonstrated that variation in soil $\mathrm{pH}$ (between different plots) may also affect plant growth and the efficient removal of pollutants by the plant. Previously, Mukherjee et al. (2014) reported the critical role of $\mathrm{pH}$ at the same study site (in Luumaki) and demonstrated its importance as an environmental variable that can regulate bacterial communities in the soil. Moreover, the $\mathrm{pH}$ gradient permits the development of considerable niche differentiation. At lower $\mathrm{pH}$ levels, Burkholderiacea and Acetobacteraceae predominate, while Pseudomonadaeceae and Sphingomonadaceae are found at higher $\mathrm{pH}$ levels. Silby et al. (2011) have reported that Burkholderiacea, Sphingomonadaceae, and Pseudomonadaeceae are known for their catabolic flexibility and are also considered the most common hydrocarbon degraders in a range of soils. Our study highlights the $\mathrm{pH}$ preferences of these bacterial groups, and the variances observed in the degradation of the studied 
organic pollutants might advocate that different microbiological processes were accountable for the deterioration of PAH and TPH.

Nutrients, such as $\mathrm{N}, \mathrm{P}$, and $\mathrm{K}$, are very important constituents for plant growth development and can also support the successful biodegradation of hydrocarbons. Some of these nutrients could become a limiting factor at elevated levels, thus affecting the biodegradation processes and inhibit biodegradation activity (Das and Chandran 2011). Many authors have described the conflicting effects of high NPK levels on the biodegradation of hydrocarbons, particularly on aromatics (Chaineau et al. 2005; Das and Chandran 2011), which is consistent with the findings in some of the plots in our study (H13, H14, and H15) where no hydrocarbon removal was observed between years. This could be due to the high concentration of nutrients, which interrupted the degradation process by affecting the microbial community in the rhizosphere. Moreover, this inhibition of hydrocarbon degradation in fertilized plots may be the result of a reduction in nutrient levels due to the acclimatization of other $\mathrm{C}$ sources in the soil and could also be ascribed to the non-invigoration of the aromatic degrading microorganisms (Carmichael and Pfaender 1997; Chaîneau et al. 2005).

Afforestation using multiple clones has been shown to strongly increase the efficiency of phytoremediation (Wei and Pan 2010). Moreover, the degradation of organic pollutants by multiclonal plantation may consequently stimulate the degradation rate of some intransigent organic pollutants, microbial functional diversity, higher soil microbial biomass, and the deterioration of enzyme activities (Chen et al. 2013). However, our results have demonstrated that this study may provide valuable information for the establishment of phytoremediation experiments in regard to the rehabilitation of polluted petroleum soils with European aspen and hybrid aspen clones.

\section{Conclusions}

We assume that the phytoremediation potential is proportional to plant survival and growth since successful tree establishment is the first requirement for long-term petroleum degradation in the soil. Moreover, tree planting is not only limited to phytoremediation but could provide critical ecological services that will positively contribute to cost-effectiveness and social perception. In this context, we have demonstrated that these European aspen clones are able to establish on polluted hydrocarbon soils. All the studied clones survived well in the polluted environment, and the survival rate of most clones was above 50\%; European aspen clone R3 (70\%) and hybrid aspen clone $291(72 \%)$ exhibited the highest survival rates. Hybrid aspen clones 14, 34, and 172 produced the largest height growth among the studied clones, with the least height growth observed in clone 134. All clones displayed good potential in terms of pollutant removal but clones R2 and 134 performed best. In the experimental area $(\sim 2 \mathrm{ha})$, the efficiency of the clones to reduce pollutant levels was only assessed in the severely polluted plots from blocks I to III, yet the survival and height growth rates of the plants were measured from all the plots of blocks I-IV. However, our results should be regarded as preliminary, as the field trial lacked sufficient replications and experimental controls, which suggests further investigation is needed. To provide more insight, additional research should be conducted in regard to the mechanisms of hydrocarbon degradation, inoculation with different bacteria, fertilizer application rates, and the addition of organic chelates in European aspen and hybrid aspen plantations.

Acknowledgments Open access funding provided by University of Eastern Finland (UEF) including Kuopio University Hospital. We would like to thank the anonymous reviewers for their valuable comments on the manuscript.

Funding information This study has been supported by a grant from the Finnish Society of Forest Sciences (grant no. 201810030), an award from the soil restoration association of Mutku ry.

Open Access This article is licensed under a Creative Commons Attribution 4.0 International License, which permits use, sharing, adaptation, distribution and reproduction in any medium or format, as long as you give appropriate credit to the original author(s) and the source, provide a link to the Creative Commons licence, and indicate if changes were made. The images or other third party material in this article are included in the article's Creative Commons licence, unless indicated otherwise in a credit line to the material. If material is not included in the article's Creative Commons licence and your intended use is not permitted by statutory regulation or exceeds the permitted use, you will need to obtain permission directly from the copyright holder. To view a copy of this licence, visit http://creativecommons.org/licenses/by/4.0/.

\section{References}

Akinola MO, Njoku KL (2007) Mutagenic effect of crude oil on the accessions of Glycine $\max$ L. (Merrill). Pak J Sci Ind Res 50(5): 330-334

Anyasi RO, Atagana HI (2018) Profiling of plants at petroleum contaminated site for phytoremediation. Int J Phytoremed 20(4):352-361. https://doi.org/10.1080/15226514.2017.1393386

Carmichael LM, Pfaender FK (1997) The effect of inorganic and organic supplements on the microbial degradation of phenanthrene and pyrene in soils. Biodegradation 8(1):1-13. https://doi.org/10.1023/ A: 1008258720649

Chaîneau CH, Rougeux G, Yéprémian C, Oudot J (2005) Effects of nutrient concentration on the biodegradation of crude oil and associated microbial populations in the soil. Soil Biol Biochem 37(8): 1490-1497. https://doi.org/10.1016/j.soilbio.2005.01.012

Chen J, Xu QX, Su Y, Shi ZQ, Han FX (2013) Phytoremediation of organic polluted soil. J Bioremed Biodegr 4:132-134

Clavel, M. (2013) Use of Aspens trees for cleaning a polluted soil at Luumäki. Natural Resources Institute. Unpublished Manuscript. 
Cocârță D, Stoian M, Karademir A (2017) Crude oil contaminated sites: evaluation by risk assessment approach. Sustainability 9(8):1365. https://doi.org/10.3390/su9081365

Das N, Chandran P (2011) Microbial degradation of petroleum hydrocarbon contaminants: an overview. Biotechnol Res Int:1-13. https:// doi.org/10.4061/2011/941810

García-Delgado C, Fresno T, Rodríguez-Santamaría JJ, Diaz E, Mohedano AF, Moreno-Jimenez E (2019) Co-application of activated carbon and compost to contaminated soils: toxic elements mobility and PAH degradation and availability. Int J Environ Sci Technol 16(2):1057-1068. https://doi.org/10.1007/s13762-0181751-6

Guarino C, Spada V, Sciarrillo R (2017) Assessment of three approaches of bioremediation (natural attenuation, landfarming and bioaugmentation-assisted landfarming) for a petroleum hydrocarbons contaminated soil. Chemosphere 170:10-16. https://doi.org/ 10.1016/j.chemosphere.2016.11.165

Guerra F, Gainza F, Pérez R, Zamudio F (2011) Phytoremediation of heavy metals using poplars (Populus spp.): a glimpse of the plant responses to copper, cadmium and zinc stress. In: Golubev IA (ed) Handbook of phytoremediation. Nova Science, New York, pp $387-413$

Guidi Nissim W, Lafleur B, Labrecque M (2018) The performance of five willow cultivars under different pedoclimatic conditions and rotation cycles. Forests 9(6):349. https://doi.org/10.3390/f9060349

Guo H, Yao J, Cai M, Qian Y, Guo Y, Richnow HH, Blake RE, Doni S, Ceccanti B (2012) Effects of petroleum contamination on soil microbial numbers, metabolic activity and urease activity. Chemosphere 87(11):1273-1280. https://doi.org/10.1016/j. chemosphere.2012.01.034

Häikiö E, Makkonen M, Julkunen-Tiitto R, Sitte J, Freiwald V, Silfver T, Pandey V, Beuker E, Holopainen T, Oksanen E (2009) Performance and secondary chemistry of two hybrid aspen (Populus tremula L. $\mathrm{x}$ Populus tremuloides Michx.) clones in long-term elevated ozone exposure. J Chem Ecol 35(6):664-678

Istrate IA, Cocârță DM, Wu Z, Stoian MA (2018) Minimizing the health risks from hydrocarbon contaminated soils by using electric fieldbased treatment for soil remediation. Sustainability 10(1):253. https://doi.org/10.3390/su10010253

Kalita M, Devi A (2012) Study on the effects of soil $\mathrm{pH}$ and addition of $\mathrm{N}-\mathrm{P}-\mathrm{K}$ fertilizer on degradation of petroleum hydrocarbon present in oil contaminated soil. Int J Chem Petrochem Technol 2(3):9-22

Kathi S, Khan AB (2011) Phytoremediation approaches to PAH contaminated soil. Indian J Sci Technol 4(1):56-63

Khan S, Afzal M, Iqbal S, Khan QM (2013) Plant-bacteria partnerships for the remediation of hydrocarbon contaminated soils. Chemosphere 90(4):1317-1332. https://doi.org/10.1016/j. chemosphere.2012.09.045

Khan AHA, Anees M, Arshad M, Muhammad YS, Iqbal M, Yousaf S (2016) Effects of illuminance and nutrients on bacterial photophysiology of hydrocarbon degradation. Sci Total Environ 557: 705-711. https://doi.org/10.1016/j.scitotenv.2016.03.068

Kołtowski M, Hilber I, Bucheli TD, Oleszczuk P (2016) Effect of steam activated biochar application to industrially contaminated soils on bioavailability of polycyclic aromatic hydrocarbons and ecotoxicity of soils. Sci Total Environ 556-567:1023-1031. https://doi.org/10. 1016/j.scitotenv.2016.05.114

Kulik N, Goi A, Trapido M, Tuhkanen T (2006) Degradation of polycyclic aromatic hydrocarbons by combined chemical preoxidation and bioremediation in creosote contaminated soil. $\mathrm{J}$ Environ Manag 78(4):382-391. https://doi.org/10.1016/j. jenvman.2005.05.005

Kuusiniemi K, Eklund J (2008) Soil pollution Finnish response to the questionnaire. Paper presented at: EU Forum of Judges for the Environment; Paris, France
Leme DM, Grummt T, De Oliveira DP, Sehr A, Renz S, Reinel SA, Ferraz ER, de Marchi MRR, Machado MC, Zocolo GJ, Marin Morales MA (2012) Genotoxicity assessment of water-soluble fractions of biodiesel and its diesel blends using the Salmonella assay and the in vitro MicroFlow ${ }^{\circledR}$ kit (Litron) assay. Chemosphere 86(5): 512-520. https://doi.org/10.1016/j.chemosphere.2011.10.017

Lukic B, Huguenot D, Panico A (2016) Importance of organic amendment characteristics on bioremediation of $\mathrm{PAH}$-contaminated soil. Environ Sci Pollut Res 23(15):15041-15052. https://doi.org/10. 1007/s11356-016-6635-z

Macaulay BM (2015) Microbial remediation of spilled petroleum. Appl Ecol Environ Res 13(1):247-262

Malá J, Machova P, Cvrckova H, Vanek T (2007) Heavy metals uptake by the hybrid aspen and rowan-tree clones. J For Sci 53(11):491497

Mohsin M (2016) Potentiality of four willow varieties for phytoremediation in a pot experiment. University of Eastern Finland, Faculty of Science and Forestry, School of Forest Sciences, pp. 38 Master's thesis in Forest Science specialization in Wood Material's Science

Mohsin M, Kuittinen S, Salam MMA, Peräniemi S, Laine S, Pulkkinen P, Kaipiainen E, Vepsäläinen J, Pappinen A (2019) Chelate-assisted phytoextraction: growth and ecophysiological responses by Salix schwerinii EL wolf grown in artificially polluted soils. J Geochem Explor 205:106335. https://doi.org/10.1016/j.gexplo.2019.106335

Mueller JG, Chapman PJ, Pritchard PH (1989) Creosote-contaminated sites. Their potential for bioremediation. Environ Sci Technol 23(10):1197-1201. https://doi.org/10.1021/es00068a003

Mukherjee S (2014) Successional and spatial patterns of bacterial communities in hydrocarbon-contaminated soils and Populus rhizosphere. [Doctoral dissertation]. Helsinki (Finland): University of Helsinki

Mukherjee S, Juottonen H, Siivonen P, Lloret Quesada C, Tuomi P, Pulkkinen P, Yrjälä K (2014) Spatial patterns of microbial diversity and activity in an aged creosote-contaminated site. ISME J 98:21312142. https://doi.org/10.1038/ismej.2014.151

Nam JJ, Thomas GO, Jaward FM, Steinnes E, Gustafsson O, Jones KC (2008) PAHs in background soils from Western Europe: influence of atmospheric deposition and soil organic matter. Chemosphere 70(9):1596-1602. https://doi.org/10.1016/j.chemosphere.2007. 08.010

Nguemté PM, Wafo GD, Djocgoue PF, Noumsi IK, Ngnien AW (2018) Potentialities of six plant species on phytoremediation attempts of fuel oil-contaminated soils. Water Air Soil Pollut 229:88. https://doi. org/10.1007/s11270-018-3738-9

Nichols EG, Cook RL, Landmeyer JE, Atkinson B, Malone DR, Shaw G, Woods L (2014) Phytoremediation of a petroleum-hydrocarbon contaminated shallow aquifer in Elizabeth City, North Carolina, USA. Remediat J 24(2):29-46. https://doi.org/10.1002/rem.21382

Nie M, Wang Y, Yu J, Xiao M, Jiang L, Yang J, Fang C, Chen J, Li B (2011) Understanding plant-microbe interactions for phytoremediation of petroleum-contaminated soil. PLoS ONE 6(3):e17961. https://doi.org/10.1371/journal.pone.0017961

Noori A, Maivan HZ, Alaie E, Newman LA (2018) Leucanthemum vulgare Lam. crude oil phytoremediation. Int J Phytoremed 20(13):1292-1299. https://doi.org/10.1080/15226514.2015. 1045122

Obida CB, Blackburn GA, Whyatt JD, Semple KT (2018) Quantifying the exposure of humans and the environment to oil pollution in the Niger Delta using advanced geostatistical techniques. Environ Int 111:32-42. https://doi.org/10.1016/j.envint.2017.11.009

Olawepo G, Ogunkunle C, Adebis O, Fatoba P (2018) Enhanced bioremediation of brass crude-oil (hydrocarbon), using cow dung and implication on microbial population. Pollution 4(2):273-280. https://doi.org/10.22059/poll.2017.240833.313 
Paccassoni F, Kalnina D, Piga L (2017) Comparative studies of oil product regulation in contaminated soil for several industrialized countries. Mater Sci Eng 251(1):012066

Panagos P, Van Liedekerke M, Yigini Y, Montanarella L (2013) Contaminated sites in Europe: review of the current situation based on data collected through a European network. Int J Environ Public Health:1-11. https://doi.org/10.1155/2013/158764

Peng S, Zhou Q, Cai Z, Zhang Z (2009) Phytoremediation of petroleum contaminated soils by Mirabilis Jalapa L. in a greenhouse plot experiment. J Hazard Mater 168(2-3):1490-1496. https://doi.org/10. 1016/j.jhazmat.2009.03.036

Pinedo J, Ibáñeza R, Lijzen JPA, Irabien A (2013) Assessment of soil pollution based on total petroleum hydrocarbons and individual oil substances. J Environ Manag 130:72-79. https://doi.org/10.1016/j. jenvman.2013.08.048

Ravindra K, Sokhi R, Van Grieken R (2008) Atmospheric polycyclic aromatic hydrocarbons: source attribution, emission factors and regulation. Atmos Environ 42(13):2895-2921. https://doi.org/10.1016/ j.atmosenv.2007.12.010

Reid BJ, Jones KC, Semple KT (2000) Bioavailability of persistent organic pollutants in soils and sediments-a perspective on mechanisms, consequences and assessment. Environ Pollut 108(1):103112. https://doi.org/10.1016/S0269-7491(99)00206-7

Salam MMA, Kaipiainen E, Mohsin M, Villa A, Kuittinen S, Pulkkinen P, Pelkonen P, Mehtätalo L, Pappinen A (2016) Effects of contaminated soil on the growth performance of young Salix (Salix schwerinii E. L. Wolf) and the potential for phytoremediation of heavy metals. J Environ Manag 183:467-477. https://doi.org/10. 1016/j.jenvman.2016.08.082

Salam MMA, Mohsin M, Pulkkinen P, Pelkonen P, Pappinen A (2019) Effects of soil amendments on the growth response and phytoextraction capability of a willow variety $(S$. viminalis $\times S$. schwerinii $S$. dasyclados) grown in contaminated soils. Ecotoxicol Environ Saf 171:753-770. https://doi.org/10.1016/j. ecoenv.2019.01.045

Semenov MY, Marinaite II, Golobokova LP, Khuriganova OI, Khodzher TV, Semenov YM (2017) Source apportionment of polycyclic aromatic hydrocarbons in Lake Baikal water and adjacent air layer. Chem Ecol 33(10):977-990. https://doi.org/10.1080/02757540. 2017.1393533

Shirdam R, Zand A, Bidhendi G, Mehrdadi N (2008) Phytoremediation of hydrocarbon-contaminated soils with emphasis on the effect of petroleum hydrocarbons on the growth of plant species. Phytoprotection 89(1):21-29. https://doi.org/10.7202/000379ar

Silby MW, Winstanley C, Godfrey SAC, Levy SB, Jackson RW (2011) Pseudomonas genomes: diverse and adaptable. FEMS Microbiol Rev 35(4):652-680. https://doi.org/10.1111/j.1574-6976.2011. 00269.x
Sivaram AK, Logeshwaran P, Subashchandrabose SR, Lockington R, Naidu R, Megharaj M (2018) Comparison of plants with C3 and $\mathrm{C} 4$ carbon fixation pathways for remediation of polycyclic aromatic hydrocarbon contaminated soils. Sci Rep 8(1):2100. https://doi.org/ 10.1038/s41598-018-20317-0

Souza EC, Vessoni-Penna TC, de Souza Oliveira RP (2014) Biosurfactant-enhanced hydrocarbon bioremediation: an overview. Int Biodeterior Biodegradation 89:88-94. https://doi.org/10.1016/j. ibiod.2014.01.007

Streche C, Cocârță DM, Istrate IA, Badea AA (2018) Decontamination of petroleum-contaminated soils using the electrochemical technique: remediation degree and energy consumption. Sci Rep 8(1):3272. https://doi.org/10.1038/s41598-018-21606-4

Tischer S, Hübner T (2002) Model trials for phytoremediation of hydrocarbon-contaminated sites by the use of different plant species. Int J Phytoremed 4(3):187-203. https://doi.org/10.1080/ 15226510208500082

Tullus A, Rytter L, Tullus T, Weih M, Tullus H (2012) Short-rotation forestry with hybrid aspen (Populus tremula $\mathrm{L} . \times$ P. tremuloides Michx.) in Northern Europe. Sci J Forest Res 27(1):10-29. https:// doi.org/10.1080/02827581.2011.628949

Udeh NU, Nwaogazie IL, Momoh Y (2013) Bio-remediation of a crudeoil contaminated soil using water hyacinth (Eichhornia crassipes). Adv Appl Sci Res 4(2):362-369

Vervaeke P, Luyssaert S, Mertens J, Meers E, Tack FMG, Lust N (2003) Phytoremediation prospects of willow stands on contaminated sediment: a field trial. Environ Pollut 126(2):275-282. https://doi.org/ 10.1016/S0269-7491(03)00189-1

Wcisło E (1998) Soil contamination with polycyclic aromatic hydrocarbons (PAHs) in Poland-a review. Pol J Environ Stud 7(5):267-272

Wei S, Pan S (2010) Phytoremediation for soils contaminated by phenanthrene and pyrene with multiple plant species. J Soils Sediments 10(5):886-894. https://doi.org/10.1007/s11368-010-0216-4

Xu M (2013) Phytoremediation with aspen trees in Luumäki. Natural Resources Institute. Unpublished Manuscript.

Zacchini M, Iori V, Mugnozza GS, Pietrini F, Massacci A (2011) Cadmium accumulation and tolerance in Populus nigra and Salix Alba. Biol Plant 55(2):383-386. https://doi.org/10.1007/s10535011-0060-4

Zalesny Jr RS, Bauer EO, Hall RB, Zalesny JA, Kunzman J, Rog CJ, Riemenschneider DE (2005) Clonal variation in survival and growth of hybrid poplar and willow in an in situ trial on soils heavily contaminated with petroleum hydrocarbons. Int J Phytoremed 7(3): $177-197$

Publisher's note Springer Nature remains neutral with regard to jurisdictional claims in published maps and institutional affiliations. 